Volume 1 Nomor 12020

http://journal.febubhara-sby.org/bharanomic

ISSN: 2774-7190

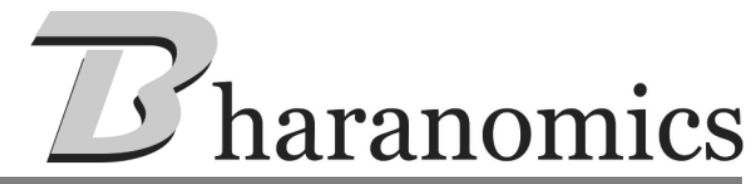

\title{
DAMPAK EKSTERNALITAS INDUSTRI TAHU TERHADAP PENDAPATAN DESA TROPODO KECAMATAN KRIAN KABUPATEN SIDOARJO
}

\author{
*Salsabila Virdausya, Mohammad Balafif, Nurul Imamah \\ Universitas Bhayangkara Surabaya, Indonesia
}

DOI: $10.46821 /$ bharanomicss.v1i1.11

\begin{abstract}
Abstrak
Eksternalitas adalah Dampak yang timbul dari adanya tindakan seseorang atau suatu pihak terhdap kondisi orang atau pihak lain. Jika dampak yang timbul memberikan keuntungan maka hal itu disebut eksternalitas positif. Sebaliknya jika dampak yang timbul memberikan kerugian maka hal itu disebut eksternalitas negatif. Rumusan Masalah dari skripsi ini adalah Bagaimana Dampak Eksternalitas dari keberadaan industri tahu terhadap pendapatan masyarakat di Desa Tropodo Kecamatan Krian Kabupaten Sidoarjo. Metode yang digunakan adalah metode penelitian kualitatif, data yang digunakan adalah data primer dan data sekunder. Berdasarkan hasil pengamatan di lapangan, industri tahu menimbulkan eksternalitas positif dan negatif yaitu penyerapan tenaga kerja, munculnya peluang usaha baru, pencemaran lingkungan, dan tingkat kesehatan masyarakat menurun. Eksternalitas yang ditimbulkan industri tahu berdampak pada peningkatan pendapatan masyarakat. Sebelum adanya industri tahu rata-rata pendapatan masyarakat berada pada tingkat rendah $<R$. 1.000 .000 sedangkan sesudah adanya industri tahu ratarata pendapatan.
\end{abstract}

Kata kunci: Eksternalitas, Industri Tahu, Pendapatan Masyarakat

\begin{abstract}
:
Externality is the Impact arising from the actions of a person or party to the condition of another person or party. If the effects that arise provide benefits then it is called a positive externality. Conversely, if the effects that arise give a loss then is called a negative externality. The problem formulation of the thesis is how does the externality impact of the exixtence of tofu industry have on people's income in Tropodo, Krian, Sidoarjo.The method used is a qualitative research method, the data used are primary data and secondary data Based on observations in the field, tofu industry creates positive and negative externalities, namely employment, the emergence of new business opportunities environmental pollution, and declining levels of public health. Externality caused by the tofu industry have an impact on increasing people's income. Before the tofu industry, the average income of the community was at a low level <Rp. 1,000,000 whereas after the industry knewthe average income of the community was at the level oh <Rp.1,000,000-Rp.5,000,000.
\end{abstract}

Keywords: Externalities, Tofu Industry, Community Incom

*Corresponding Author:

Hal: 1-8

Email: cacavirdausya @ gmail.com 


\section{PENDAHULUAN}

Industri adalah seluruh bentuk kegiatan ekonomi yang mengolah bahan baku atau memanfaatkan sumber daya industri sehingga menghasilkan barang yang mempunyai nilai tambah atau manfaat yang lebih tinggi, termasuk jasa industri. Industri mempunyai peranan yangstrategis dalam penyediaan lapangan kerja, menyediakan barang dan jasa yang bermutu serta dapat ditempuh dengan cara memanfaatkan sumber daya alam. Industri di kabupaten Sidoarjo sudah gencar dikembangkan. Ada 41 macam industri kecil dan menengah yang berkembang di Sidoarjo. Hal ini dikarenakan Kabupaten Sidoarjo merupakan salah satu kawasan penyangga kota Surabaya, lokasi yang berdekatan dengan ibukota propinsi membuat wilayah kabupaten sidoarjo sangat strategis untuk pengembangan industri kecil dan menengah hal ini ditunjang dengan mudahnya aksebilitas, sarana dan prasarana serta jaringan transportasi dan komunikasi sehingga mempermudah berinterkasi dengan kota/kabupaten lain. (Aprikan Yoga Kusidarmono,2016)

Salah satu jenis makanan ringan yang terkenal di Sidoarjo adalah Tahu. Salah satu daerah yang terkenal dengan produksi tahu adalah Desa Tropodo. Desa Tropodo merupakan salah satu desa di Kecamatan Krian yang terkenal akan industri tahu. Industri tahu di desa Tropodo merupakan salah satu produk unggulan dari Sidoarjo. Desa Tropodo sendiri sudah memiliki sentra industri tahu, dilihat dari data tahun 2015 masih ada 38 unit dan sekarang berjumlah 62 unit yang masih berproduksi. Keberadaan industri tahu yang ada memberikan dampak positif bagi masyarakat. Banyaknya usaha industri tahu yang berada di lingkungan masyarakat, mengakibatkan banyak masyarakat yang mengeluhkan dampak buruk dari kegiatan usaha industri tahu karena masih banyak produsen tahu yang mengabaikan penanganan limbah dariusahanya.

Ketika suatu industri dapat menimbulkan suatu output. Disisi lain industri juga menimbulkan dampak seperti terbukanya lapangan pekerjaan, menyerap tenaga kerja dan mengurangi tingkat pengangguran dan meningkatkan pendapatan masyarakat sekitar.

Aktivitas yang dilakukkan melalui mekanisme pasar tidak akan menimbulkan berbagai masalah.Keterkaitan suatu kegiatan dengan kegiatan lain yang tidak memalui mekanisme pasar adalah apa yang disebut dengan eksternalitas. (Istikomah, 2018) . Setiap kegiatan yang dilakukkan oleh manusia pasti memberikan dua akibat, baik akibat positif maupun akibat negatif.

Industri tahu bertempatan ditengah-tengah pemukiman warga desa, sehingga kehidupan masyarakat pedesaan pada umumnya akan sangat bergantung pada keadaan alam sekitarnya terutama dalam kelangsungan hidup soisal ekonominya. Suatu kegiatan atau transaksi ekonomi dapat bersifat positif maupun negatif dalam kenyataannya, baik dampak negatif mapupun dampak positif bisa terjadi secara bersamaan maupun simultan. (Eriska nur oktaviani, 2018). Keberadaan industri tahu di desa Tropodo diharapkan dapat meningkatkan pendapatan masyarakat setempat, selain itu juga dapat membuka lapangan pekerjaan baru bagi masyarakat sekitar. Dengan meningkatnya pendapatan masyarakat sekitar akan meningkat dan kesejahteraan masyarakat sekitar juga ikut meningkat. 
Maka dari paparan latar belakang yang ada, penulis tertarik untuk melakukkan penelitian dengan judul: "Dampak Eksternalitas Industri Tahu Terhadap Pendapatan Masyarakat di Desa Tropodo Kecamatan Krian Kabupaten Sidoarjo".

\section{TINJAUAN PUSTAKA}

\section{Eksternalitas}

Menurut Rinawati (2014:50) Eksternalitas adalah biaya atau manfaat transaksi pasar yang tak tercermin dalam harga. Tindakan konsumsi atau produksi dari suatu pihak mempunyai pengaruh terhadap pihak lain dan tidak ada kompensasi yang dibayar oleh pihak yang menyebabkan atau kompensasi yang diterima oleh pihak yang terkena dampak tersebut. Apabila ada eksternalitas maka ada pihak ketiga yang terkena dampak produksi dan konsumsi. Pihak ketiga adalah mereka yang menanggung beban misalnya karena air atau udara yang tercemar.

Eksternalitas timbul karena tindakan konsumsi atau produksi dari satu pihak mempunyai pengaruh terhadap pihak yang lain dan tidak ada kompensasi yang dibayarkan oleh pihak yang menyebabkan atau kompensasi yang diterima oleh pihak yang terkena dampak tersebut. Menurut Mangkoesoebroto (2014:43) Ada dua syarat terjadinya eksternalitas yaitu:

a. Adanya pengaruh dari suatutindakan

b. Tidak adanya konpensasi yang dibayarkan atau diterima

\section{Dampak Eksternalitas}

Eksternalitas ditinjau dari dampaknya eksternalitas dapat terbagi menjadi dua (Prasetyia, 2013:6-9) yaitu:

\section{Eksternalitas Positif}

Eksternalitas positif adalah tindakan seseorang yang memebrikan manfaat bagi orang lain, tetapi manfaat tersebut tidak dialokasikan di dalam pasar. Jika kegiatan dari beberapa orang menghasilkan manfaat bagi orang lain dan orang yang menerima manfaat tersebut tidak membayar atau memberikan harga atas manfaat tersebut maka nilai sebenarnya dari kegiatan-kegiatan tersebut tidak tercermin dalam kegiatanpasar.

\section{Eksternalitas Negatif}

Eksternalitas negatif adalah biaya yang dikenakan pada orang lain di luar sistem pasar sebagai produk dari kegiatan produktif. Seperti tercemarnya lingkungan, polusi, tercemarnya udara.

\section{Pendapatan}

Pendapatan merupakan penghasilan yang diperoleh masyarakat yang berasal dari pendapatan kepala rumah tangga maupun pendapatan anggota-anggota keluarga. Penghasilan tersebut biasanya dialokasikan untuk konsumsi, kesehatan, maupun pendidikan dan kebutuhan lain yang bersifat material. Indikator pendapatan digolongkan menjadi 3 item (Fahrudin, 2012:57) yaitu:

a. Tinggi $\mathrm{Rp}>5.000 .000$

b. Sedang Rp. 1.000.000-5.000.000

c. Rendah Rp. $<1.000 .000$ 


\section{Industri}

Menurut Hasibuan dalam Fahrizal (2016) pengertian industri sangat luas, dapat dalam lingkup makro maupun mikro. Secara mikro Industri adalah kumpulan dari perusahaan-perusahaan yang menghasilkan barang-barang yang homogen, atau barang-barang yang mempunyai sifat yang saling mengganti erat. Dari segi pembentukan pendapatan yakni cenderung bersifat makro. Industri adalah kegiatan ekonomi yang menciptakan nilai tambah jadi batasan industri yaitu secara mikro sebagai kumpulan perusahaan yang menghasilkan barang sedangkan secara makro dapat membentuk pendapatan.

Industri sebagai kegiatan untuk menghasilkan barang-barang secara massal dengan mutu yang bagus untuk kemudian dijual belikan dan diperdagangkan. Kartasapoetra dalam Fahrizal (2016).

\section{Tenaga kerja}

Menurut Mulyadi tenaga kerja sebagai penduduk dalam usia kerja (berusia 15-64 tahun) atau jumlah seluruh penduduk dalam suatu negara yang dapat memproduksi barang dan jasa jika ada permintaan terhadap tenaga mereka, dan jika mereka mau berpartisipasi dalam aktifitas tersebut.

Menurut Murti tenaga kerja adalah individu yang menawarkan keterampilan dan kemampuan untuk memproduksi barang atau jasa agar perusahaan dapat meraih keuntungan dan untuk itu individu tersebut akan memeperoleh gaji atau upah yang sesuaidimilikinya.

\section{METODE PENELITIAN}

a. Lokasi dan waktu penelitian

b. Desa Tropodo Kecamatan Krian Kabupaten Sidoarjo selama 3 bulan.

c. Pendekatan penelitian : Pendekatan kualitatif

d. Metode Pengumpulan Data: Triangulasi Gabungan, Observasi, Wawancara Mendalam dan Dokumentasi.

e. Analisis Data: Pengumpulan Data, Reduksi Data, Penyajian Data, Penarikan Kesimpulan.

\section{HASIL DAN PEMBAHASAN}

Eksternalitas yang Timbul Akibat Adanya Industri Tahu Desa Tropodo

Industri tahu Desa Tropodo dalam melakukkan aktivitas produksinya tidak hanya menghasilkan barang atau jasa tetapi juga secara langsung maupun tidak langsung juga memberikan dampak yang berupa positif maupun negatif, manfaat ataupun kerugian pada masyarakat sekitarnya yang disebut dengan eksternalitas.

\section{Eksternalitas Positif}

Eksternalitas positif merupakan dampak yang memberikan keuntungan atau yang menguntungkan dari suatu tindakan terhadap pihak lain

a. Penyerapan TenagaKerja

Tenaga kerja merupakan setiap orang yang mampu melakukkan pekerjaan guna menghasilkan barang atau jasa untuk memenuhi kebutuhan sendiri maupun masyarakat. Dapat kita lihat fakta bahwa sekarang semakin banyak anak-anak 


\section{Bharanomics}

bangsa yang menempuh pendidikan di perguruan tinggi guna menjadi sumber daya manusia yang memiliki potensi diri. Dengan demikian semakin banyaknya tenaga kerja harus diimabngi dengan luasnya lapangan pekerjaan. Sehingga masyarakat tidak harus mencari pekerjaan di tempat lain. Karena sejak berdirinya industri tahu, masyarakat memiliki kemudahan untuk mendapatkan lapangan pekerjaan atau menciptakan usaha baru yang dapat meningkatkan perekonomian keluarga. Hal ini akan berdampak pada berkurangnya pengangguran di sekitar industri tahu khususnya.

Dari hasil observasi dan wawancara dengan Sekertaris desa Tropodo bahwa hampir 50\% masyarakat desa Tropodo bekerja di industri tahu. Berdirinya industri tahu di rasakan telah membantu masyarakat untuk mendapatkan pekerjaan yang dekat dengan tempat tinggal dengan upah yang dapat membantu pengeluaran konsumsi sehari-hari dan peningkatan perekonomian keluarganya. Dengan berdirinya industri tahu kini sudah banyak menyerap tenaga kerja sebanyak 7-14 orang setiap industri. Akan tetapi tidak semua masyarakat Desa Tropodo bekerja pada industri tahu.

b. Terciptanya Peluang UsahaBaru

Dengan adanya industri tahu ini tidak hanya membuka lapangan pekerjaan bagi masyarakat sekitar tetapi dapat pula membuka peluang usaha baru bagi masyarakat sekitar diantaranya ialah:

1. Berdagang

Berdirinya industri tahu banyak membuka beberapa macam usaha dagang sekitarnya. Berdagang salah satu cara untuk menningkatkan pendapatan masyarakat. Seperti halnya usaha dagang yang dilakukkan oleh masyarakat sekitar industri tahu. Adapun usaha yang terdapat dikawasan industri tahu yaitu pedagang tahu sumedang, pedagang tahu bulat dan juga warung sembako dan juga warung makan. Dengan adanya industri tahu masyarakat disarankan lebih berinovasi untuk memproduksi aneka macam tahu jadi tidak memproduksi tahu putih saja.

Hal itu tidak hanya berlaku bagi para pengrajin tahu namun juga berlaku juga pada masyarakat Desa Tropodo yang lain yang tidak mempunyai industri tahu. Seperti contoh Ibu Mas'amah setiap harinya Ibu Mas'amah dikirimin tahu dari salah satu industri tahu yang berada di Desa Tropodo untuk dijual kembali di tokonya sehingga mereka tidak perlu untuk memproduksi tahu sendiri.Maka diharapkan masyarakat lebih inovasi dan inofatif dalam mengolah tahu seperti Tahu susu, Tahu keju maupun macam olahan tahu lainnya agar terdapat tambahan nilai jual.

\section{Eksternalitas Negatif}

Eksternalitas Negatif adalah kebalikan dari eksternalitas positif yang sifatnya merugikan. Eksternalitas yang memberkan dampak merugikan dari suatu pihak terhadap pihak yang lain. Selain adanya eksternalitas positif dalam memproduksi produknya industri tahu memberikan eksternalitas negatif dari industri tahu yaitu: 
Bharanomics

Vol. 1 No. 12020

Salsabila Virdausya dkk., Dampak Eksternalitas Industri Tahu

a. Pencemaran lingkungan

Industri tahu dalamemproduksi tahu pastilah mempunyai limbah, limbah adalah salah satu kerusakan alam akibat ulah manusia, yang secara langsung atau tidak langsung akan di rasakan oleh masyarakat sekitar. Bahwa limbah dapat merusak lingkungan yang pada akhirnya akan membahayakan kehidupan manusia itusendiri.

Salah satu industri milik bapak Saipul yang tempatnya dekat dengan sungai, itu mengakibatkan sungai mengalami pencemaran dan banyak sampah yang terdapat pada pinggir-pinggir sungai. Tidak hanya dekat dengan sungai tetapi juga sangat dekat dengan pemukiman warga yang membuat bau yang menyengat pada saat proses pembuatan tahu itu sangat menganggu warga sekitar.

Masalah pembuangan limbah tahu memang sudah menjadi masalah turun temurun bagi pengrajin tahu. Sebagian pengrajin tahu sudah menggunakan Ipal untuk mengolah limbah tahu apabila paralon mengalami kebocoran harus ditambal ataupun diganti dengan paralon baru. Seperti yang dilakukkan oleh salah satu industri milik Bapak Zainal yang menggnakan ipal untuk mengolah limbah tahu. Berbeda dengan industri tahu milik Bapak Saipul yang pembuangan limbahnya masih menggunakan galian tanah sebagai tempat pembuangan limbah karena minimnya dana dan industri Bapak Saipul ini masih setara dengan industri tahu rumahtangga.

b. Menurunya kesehatanmasyarakat.

Industri dalam menjalankan produksinya akan menimbulkan dampak langsung maupun tidak langsung yang dirasakan oleh masyarakat sekitar. Dampak yang dirasakan secara tidak langsung yaitu menurunnya kesehatan masyarakat sekitar. Banyak pengrajin tahu masih menggunakan bahan bakar menggunakan sampah plastik yang mengakibatkan asap hitam yang mencemari udara sekitar. Seperti industri milik bapak Saipul yang masih menggunakan bahan bakar sampah plastik yang dicampuri dengan kayu bakar. Menurut bapak Saipul mahalnya kayu bakar maka bapak saipul masih menggunakan sampah plastik yang dicampur dengan kayu bakar untuk bahan bakar pembuatan tahu. Hal ini banyak masyarakat sekitar yang mengeluhkan dari asap hitam yang timbul. Masyarakat banyak mengeluhkan sesaknya dada atau nafas. Banyak masyarakat menderita infeksi saluran pernafasan akut yang biasa disebut dengan ISPA yang diakibatkan oleh menghirup udara yang tercemar. Tidak hanya menderita ISPA masyarakat juga banyak mengeluhkan batuk hingga radang tenggorokan akibat seringnya menghirup udara yang tercemar akibat asap hitam yang timbul pada saat proses pembuatan tahu. Industri juga menyadari bahwa mereka mempunyai kewajiban untuk pentingnya menjaga lingkungan, melindungi dan memberikan kontribusi kepada masyarakat yang merasa dirugikan terutama kepada pihak yang berkepentingan lingkungan alam sekitar kesejahteraan bersama, industri memberikan kompensasi kepada masyarakat sekitar dengan memberikan uang pada setiap bulan sekali. Adapula yang memberikan sembako pada saat hari raya atau lebaran. 


\section{Pendapatan Masyarakat dari Keberadaan Industri \\ Tahu Tingkat Pendapatan}

Pendapatan menjadi salah satu faktor yang menentukan apakah masyarakat dikatan sejahtera atau tidaknya. Pendapatan ini berupa materi yang dapat di gunakan untuk mencukupi kebutuhan sehari-harinya masyarakat. Pendapatan merupakan penghasilan yang diperoleh masyarakat yang berasal dari pendapatan kepada kepala rumah tangga maupun pendapatan anggota-anggota keluarga. Tingkat pendapatan bersih dari masing-masing individu berbeda-beda sesuai dengan status pekerjaan dan pekerjaan sampingan yang menjadi pendapatan tambahan setiap individu.

Masyarakat Desa Tropodo mengatakan bahwa pendapatan mereka dulu dengan pendapatan saat ini jauh lebih baik. Hal ini karena pendapatan mereka saat ini jauh lebih baik di bandingkan dengan pendapatan mereka dahulu. Dahulu bapak Saipul Yang sebelumnya bekerja hanya sebagai karyawan dengan upah Rp. 1.500.00 dari pengalaman menjadi karyawan industri tahu sekarang memiliki industri tahu sendiri dengan pendapatan tetap Rp. 5.000.000 hal ini membuktikan bahwa industri tahu mempunyai peran untuk meningkatkan pendapatan masyarakat. Selain dapat meningkatkan pendapatan karyawannya sendiri adanya industri tahu Tropodo dapat juga meningkatkan pendapatan masyarakat sekitar salah satunya yaitu ibu Mas'amah yang awalnya hanya sebagai IRT yang mengandalkan gaji dari suaminya saja dengan adanya industri tahu bu Mas'amah dapat membuka toko sembako dan juga menjual tahu yang dibelinya langsung dari industri tahu, pendapatan yang ibu Mas'amah sekarang sekitar Rp.2.000.000 hal ini membuktikan bahwa pendapatan Ibu Mas'amah mengalami peningkatan pendapatan. Karyawan industri tahu tropodo pun juga merasakan adanya peningkatan pendapatan tetap mereka rata-rata lebih dari Rp. 2.000.000. jika ada pendapatan tambahan dari hasil lembur mereka atau juga dari pesenan tahu yang meningkat setipa harinya. Dengan adanya peningkatan pendapatan maka masyarakat dapat memenuhi kebutuhannya sehari-hari.

\section{SIMPULAN}

Berdasarkan dari hasil dan observasi di lapangan, industri tahu menimbulkan dampak eksternalitas positif dan negatif. Dampak positif diataranya yaitu penyerapan tenaga kerja dan peluang usaha baru atau munculnya usaha-usaha baru. Sedangkan dampak negatinya yaitu pencemaran lingkungan dan menurunnya kesehatan masyarakat. Industri tahu juga memberikan kompensasi kepada masyarakat berupa uang ataupun sembako pada tiap hari raya. Eksternalitas yang terjadi pada industri tahu berdampak pada peningkatan pendapatan masyarakat sekitar. Sebelum adanya industri tahu ratarata pendapatan yang diperoleh tidak lebih dari Rp.1.000.000 dan sesudah adanya industri tahu rata-rata pendapatan masyarakat sekitar lebih dari Rp.1.000.000. Dengan adanya peningkatan pendapatan masyarakat mampu memenuhi kebutuhan pokok dan juga mampu membiayai anak-anaknya sekolah.

\section{DAFTAR PUSTAKA}

Fahrizal, M. A. (2016). Analisis Eksternalitas Pabrik Kerupuk Di Desa Branti Raya Kecamatan Natar Kabupaten Lampung selatan. Skripsi. FEB 


\section{Bharanomics}

Vol. 1 No. 12020

Fahrudin, A. (2012). Pengantar Kesejahteraan Sosial . Bandung: Refika Aditama

Mulyadi, S. (2014). Ekonomi Sumber Daya Manusia Dalam Perspektif Pembangunan. Jakarta: PT.Raja Grafindo Persada

Murti, S., \& Siprihanto, J. (2014). Pengantar Bisnis Dsar-Dasar Ekonomi Perusahaan. Yogyakarta: Liberty.

Kusidarmono, A. Y. (2016). Faktor-faktor yang mempengaruhi Eksistensi Industri Tahu Pada Lingkungan Kecil (Lik) Di Desa Tropodo Kecamatan Krian Kabupaten Sidoarjo. Jurnal Pendidikan Geografi, Vol 1 No 1

Mangkoesobroto, G. (2014). Ekonomi Publik Edisi 3. Yogyakarta: BPFEYOGYAKARTA

Istikomah. (2018). Analisis Eksternalitas Peternakan Ayam Terhadap Pendapatan Masyarakat dalam Perspektif Ekonomi Islam. Ekonomi Syariah, Universitas Islam Negeri Raden Intan, Lampung. Skripsi.FEB.

Oktaviani, E. N. (2018). Dampak Eksternalitas industri Pengolahan Karet Terhadap Kondisi Sosial Ekonomi Masyarakat Dalam Perspektif Ekonomi Islam. Skripsi, FEB

Prasetyia, F. (2013). Bagian V: Teori Eksternalitas . Malang: Fakultas Ekonomi dan Bisnis Universitas Brawijaya

Rinawati, A. (2014). Eksternalitas sebagai salah satu kegagalan pasar.

Purworejo: FKIP Universitas Muhammadiyah

Sugiyono. (2017). Metode Penelitian Kunatitatif, Kualitatif dan RPD. Bandung : Alfabeta, CV. 